\title{
LIONEL OBADIA
}

\section{Comparing 'religious diversities' Issues, perspectives and problems}

$\mathrm{T}$ his paper aims at reopening the debate regarding 'religious diversity' in religious studies. A review of (recent or ancient) literature demonstrates that we have not finished with the complexity of the issue of 'diversity', whether in academic or social debates. Furthermore, diversity must not only be taken seriously, but impels us towards a comparative methodology in order to highlight the variations of the forms, dynamics, effects and contexts of diversity. As such, Asian countries represent a very interesting location for an epistemological deconstruction of the Western-style and monotheistic-centred concept of 'religious diversity', as it is often used in religious studies and the social sciences.

THE SUBJECT MATTER OF THIS SPECIAL ISSUE is anything but new: religious diversity has already been widely discussed in theology, philosophy, history and sociology. (Too) many times, however, diversity has been measured against the yardstick of the changing face of monotheistic models of religion (mainly Christianity). Asian religions have stood at the opposite end of a spectrum of analytical models in religious studies since Max Weber's classic analysis of Asian religions as mixed systems of beliefs per se (especially in India, Weber 1958). This distinction is, nevertheless, rather problematic, and calls for a closer examination of the conceptual status of diversity, and of the forms it assumes in Asian contexts.

Western modern societies have (only) recently recognized that they were subject to global forces and reshaped by global cultural processes. Massive migrations certainly, but also the mediatization of culture by electronic networks, have induced a drive towards multiculturalism. Cultures are 'flowing' throughout the world, reshaping the 'scapes' of a world (Appadurai 2001) where boundaries tend to be weakened by transnational connections (Hannerz 1996), territories are undermined by societies and cultures 'in motion' (Tomlinson 1999, Waters 2001) and can even be entirely dissolved, in the more extreme situations. In such a context of what we can call an open economy of cultural exchanges, hybridization processes have been designed as the rule or main outcome of globalization (García Canclini 1995). This recognition of such cultural influences 'external' to nation states has also had an impact on the revival of local forms of culture and religion. Thinking, writing, and talking about diversity has become commonplace: a huge body of academic literature - but also other media, including the press and the internet - have sounded with the echoes of new forms of culture, the reinvention of traditions, claims for cultural or religious purity, or quite the reverse, cultural or religious métissages. In short, they have massively offered to the concept of 'diversity' its conditions of existence and the grounds for its legitimacy. But the concept also lies in the heart of the social and political programmes of multicultural societies, and has been located at the forefront of public debates (in France, Wieviorka 2008). Positive discrimination, definitions of 'ethnic' quotas, protective measures for minorities and public policies have been designed with the explicit aim of protecting and promoting the values of diversity against the risk of reducing the scope and the social extension of diversity. However, diversity and moreover multiculturalism present challenges both in societal and academic circles. International institutions like UNESCO have continually placed an emphasis on the need to explicitly frame policies towards cultural and, to a certain extent, religious diversity, while scholars have a more circumspect view of the complexity of forms, dynam- 
ics and effects of diversity (Vertovec 2010). And it is true that in many countries, in rather different local conditions, but under the pressure of the same global forces, the diverse shapes of religions have become a common concern in the context of a rising visibility of religions in the public sphere (Habermas 2006), and especially (but not only) of more perceptible tensions between religious communities (Foley 2011).

Yet 'diversity' is not only a political and ideological issue. It is also - furthermore - a key concept in the social sciences and humanities, and a crucial issue for the understanding of human societies. It is a 'philosophical challenge' (Quinn and Meeker 2000), regarding the issue of human rights (Bloom et al. 1996), or ideological and political underlying values (Baghramian and Ingram 2000). Even so, many of these works have considered diversity to be an issue for the ideological and sociological hegemony of Christianity (in a rather 'politicallyoriented' definition of diversity), or treat diversity as a methodological tool consisting in the study of religions in parallel but independently from each other in order to establish the diversity of specific views or conceptions of social or cultural topics.

It is a commonplace to state that 'diversity' covers a variety of forms and natures: biological, cultural, social or ethnic diversities represent singular models of different realities. They are all 'diverse' but each of them presents a unique model of reality. If the perspective remains focused on the topic of 'cultural and religious diversity', however, one may wonder to what extent it exemplifies the new horizon of modern societies, as goes the common wisdom in globalization studies and in the different modernist paradigms (postmodernity, multiple modernities, post-postmodernity). There is an urgent need to historicize the concepts by which societies frame themselves, and to locate them in social, ideological and theoretical contexts. In French-speaking countries, for instance, the term 'diversity' is more widespread, whereas English-speaking nations have a preference for 'multicultural' or 'hybrid' - even if both terms by no means refer to equal forms or processes.

Some anthropologists consider that globalization offers specific conditions for the mixing of cultures (Hannerz 1996, Mathews 2000) and religions (Luca and Burrell 1999, Meintel and Leblanc 2003). Other scholars in globalization studies have a more critical stance towards (cultural) hybrid identity as false creolization (Friedman 1994). This brief outline of the academic issue of diversity demonstrates how contrasting are the views on religion in the context of globalization. And regarding this debate, anthropologists and scholars in comparative and cultural studies have already engaged in a controversy against the globalist and (post or not-post)modernist narratives that mainly reflect analytical views of the world and of history assessed against the yardstick of the historical path of Western or 'modern' societies. The two and three last decades have been the occasion for a massive decolonization of cultural thinking (from Stuart Hall to Homi Bhabha). Even if they are not actually responsible for it, anthropologists have pointed to the need for an examination of transcultural and transhistorical comparativism in the study of diversity - in religious and in cultural diversity 'as seen from fieldwork' and especially in the context of the escalating visibility and politicization of religion (Robertson 1992, Geertz 2000).

In more specific terms, it is possible to consider 'diversity' in the regime of pragmatics rather than in the sole realm of factual reality: diversity is above all a discourse by which the idea of bringing together different communities of ideas, practices, and faiths, is expressed - for better or for worse, according to the political context in which it is termed. As such, this discourse makes diversity a collective representation, and depending upon sociological realities - but also ideological preferences - diversity can be understood as an ideal of a mixed society in which people aspire to live in peace, or as a repulsive reference for individuals or groups who accuse the cultural and religious Others of being responsible of the decay or 'decadence' of the society. Depending on the theory and ideological backgrounds, then, diversity can be viewed as an opportunity or a threat to the stability of cultures, societies and religious traditions. Looking beyond the analysis in terms of pragmatics, 'diversity' in the lexicon of social sciences and religious studies is not only a reality apprehended by the tools of description. It is also a concept, and moreover a theoretical model, beyond the social and political uses it is frequently engaged in or subjected to. Furthermore, for scholars in religious studies, the reasons why diversity is so important can be explained in at least two different ways. In the context of high modernity and globalization, religious landscapes were supposed to be more and more characterized by the presence of distinct forms or expressions of different religions or spiritualities in a global landscape, or 
new religioscapes (Waters 2001). The 'pluralization' or 'diversification' of religion has thus become one among a number of new and fashionable concepts, but mediatization, mission, or migration processes are responsible for this 'blending' of religions (Csordas 2009) in the context of a global hybridization of cultures (García Canclini 1995). A second reason can be found in the supremacy of 'the great religions' (in Max Weber's sense of the term, i.e. influential theistic systems in history) over 'small' ones: local cults, ethnic religions, and popular beliefs have everywhere around the world been put under pressure by large and powerful religious systems. And in this respect, the effects of globalization on religions and religious diversity are contrasted and raise opposing views. On the one side, promoters of the theory of 'bricolage' and hybridization (Hervieu-Léger 2000) and some theologians (e.g. Küng 1992) believe that global forces offer a chance for religions to exist in a pluralistic world and even allow oral traditions to take their revenge on scriptural ones (Luca and Burrell 1999). On another side, scholars with less optimistic views concerning globalization have pointed out that it is in fact the same world. If there is a tragedy of 'diversity', it is the same that was encountered by 'witchcraft' (as for Jules Michelet, in La sorcière, 1898) or 'magic powers' (for Ernesto de Martino 1948): the term is not only assessed for its conceptual relevance, it also carries ideological connotations, and is subject to the violence of words on religious realities often deminished by an authoritarian, historical master-narrative of religions: 'globalization-as-diversification' or 'globalization-against-diversity'.

\section{Issues and problems: a brief overview}

The epistemological status of 'diversity' is rather fuzzy, which is why definitions of the term are torn between a tendency to frame it in relation to empirical facts, and another tendency which focuses on a much more abstract, conceptual model. Furthermore, and besides, the ontological status of diversity is under critical examination, recalling that, in modern societies, the term still refers to a social issue and an academic subject-matter. Is it an issue for modern societies only? Contemporary theories in religious studies are inclined to portray 'secular modernity' and 'globalization' as 'eras of metissage and hybridity' (Obadia 2010) against the 'ancient regime' of religious times - those times where one religious system, namely Christianity, had an alleged hegemonic position and ruled culture and society. This model, framed after the history of Christianity in Western Europe, has been criticized for being too ethnocentric and hardly transposable elsewhere, especially in Asian contexts (Clémentin-Ojha 1997).

Not exactly in the same vein, but regarding almost similar issues, another problem is the extension of the concept of diversity. Regardless of the tradition under examination, the question is: if diversity is a certain way of blending religions, when it is about mixing, what exactly is being mixed? There are several possibilities, and most of the time, for understandable reasons (of visibility), diversity can be measured, whether between large systems of official religions or within these systems, in the case of internal diversification such as schisms, ramifications into 'branches' or 'schools', 'lineages' or 'sects'. Another possibility is to take into account the encounters and cross-fertilizations of official religions and less established, institutionalized and authorized systems of belief falling under the category of 'magic' or 'superstition'. To our knowledge, there is no known example in history of a 'great religion' which is not associated with a more or less hidden layer of 'magic' or 'animism'. Accordingly, anthropological and historical views of religion have highlighted the surface of 'popular' cults and the corresponding miscellaneous beliefs that represent a significant proportion of the expressions of religion in society - Western and non-Western, Antique or modern. Religions - if they ever have been 'pure' ones - also blend with other repertoires and in the context of highly modern societies, the emerging 'spiritualities' not only create genuine systems (Heelas and Woodhead 2005) but also borrow in various secular and sacred catalogues of ideas and practices, be they old(-fashioned) traditions or more recent religious (cultic) movements. On the larger scale of what is nowadays labelled 'global history', there are obviously differentiated careers of diversity, depending on times, spaces and contexts, traditions and actors: if religious diversity is, as such, everywhere, the forms it assumes are conditional on the 'somewhere' it is rooted in. Moreover, politically speaking, diversity raises crucial epistemological issues. First, empirical, recordable expressions of religious diversity are torn between ostensible and discreet forms, between traditions and systems, but a further question remains: is diversity the norm or it is the exception, is it contingent or widespread, is it a residual effect of the course 
of history ('diversification') or a symptomatic, recurrent feature of societies? And second, diversity partakes of the encounters between, and the mixing of, different religious norms, but is in itself a normative framework, entrenched in a certain narrative of history, and history of religions.

\section{Narratives, imagination and resistance to diversity}

The commonly accepted narratives in the modern history of religion are based on the premise that the past used to be unified before times of 'hybridization' (Luca and Burrell 1999). John Tomlinson has been critical of these modernist narratives, in which ancient cultures and societies are lost 'treasures' which have been altered by time (Tomlinson 1999). In a similar perspective, I have also discussed the starting point of 'diversification' processes in history on the basis of a partial premise, that is to say, the primary unity of religion as a Christian narrative and distorted modern secular views on diversity (Obadia 2014). Scrutinizing history from such a skewed angle is problematic when it is concerned with framing models of religious change. Moreover, this inclination also highlights recent religious dynamics, and especially the religious organizations whose intention is to reinstall the unity of religions or the unity of one religion in the present. Three trends epitomize such a desire to return to an idealized unity, or to design the future of religion in terms of unity: 1) Ecumenical movements or religious coalitions speaking 'with one voice' (on issues like climate change, for instance); 2) more theoretically, the alignment of religions on the model of a single monotheism, on a global scale (Beyer 1994, 1998), and, 3) the revival of radical postures of extremism in religions, especially in highly visible minorities (Wahhabism, Pentecostalism, orthodox Judaism, and so on) where religious diversity is erased by the normative unification of habits, diets, customs, clothes, and so on.

The above-mentioned dynamics and phenomena might create the illusion of a world torn between the forces of unification and the opposite forces of diversification. Under the layer of an apparent standardization of behaviours and the unification attempts of scripturalist traditions (monotheistic ones in particular) and their rewriting of history (past, but above all, future), or the fragmentation of religious systems, though, other dynamics surfaced. The unity versus diversity' nexus can indeed be regarded from a very different viewpoint as soon as one takes into account a kind of sedimental crystallization and stratification of hidden diversities ('popular,' 'private', 'superstitious', whatever the label applied) beyond the surface of official traditions mixing with or 'purifying' themselves of foreign influences. Hence, an 'archaeology' of the sedimental layers of diversity reveals that diversity can be visible on the synchronic level, or discreet or clandestine, on a diachronic one. Besides, Western and non-Western diversities vary in form, historical career and social acceptability: the diversity of 'religions' in Roman Catholic France is more problematic (Obadia 2015) than the diversity of 'teachings' (jiao or sasana respectively) in China or India. Recent theories insist on a correspondence between modernity and diversity, or between globalization and fragmentation, and in both cases with a dislocation and dispersion of culture and religion. However, it is not certain that we live in times of religious diversity - as goes the slogan. The effects of modernity and of globalization may be much more complex and ambiguous than they appear to be at first sight. 'Open religious economies' or a 'market structure' of religions can indeed create both a landscape of multiple traditions and dynamics of religious change (conversions), as well as identity crispation' (Voas et al. 2002). Additional to this, diversity and unification are not the only processes we can observe: matrices of absorption and reinterpretation of religions are contradictory with syncretism. As an example, does the fashion of Asian-styled meditation in the West mean a Westernization of an Asian tradition, or an Easternization of the West (Obadia 2011)? Besides, the success of Asian meditation has brought about the (re)invention of Jewish, Christian and even Muslim, as monotheistic acculturations of Asian traditions and, therefore, less an increase in and rather a reduction of diversity (Obadia 2013).

Finally, the problem of diversity is also its location on the scale of history: do we have to install diversity at the origins of civilizations (as for Hume in 1757) or at the end of history (Weber 1958)? Having discussed the issues surrounding diversity, the debate must now turn to the very concept itself. I suggest that, again, regardless of the cultural or historical context, a difference can be distinguished between instituted diversities and instituting diversities, between stable forms of diversities and processual diversities or diversities in the making. Under the first category are ranged syncretic cults (such as Afro-Brazilian cults, Santeria, 


\section{Levels of Religious Diversity}

Countries are shaded according to level of religious diversity

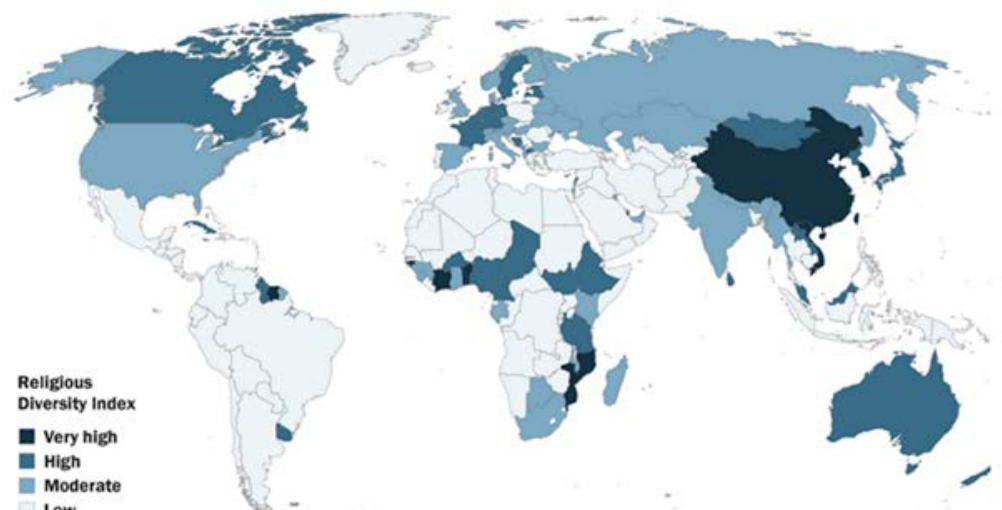

Based on Religous Diversity Inder scores. For more informstion about how the index is calculated, see the Methodobgy. Data are for 2010 Global Religlous Diversity;'April 2014

PEWRESEARCH CENTER account the fact that religious diversity not only varies over time, but also in space, can we consider that religious diversity is expanding or reducing in our contemporary world? The Pew Research Center's 2014 census ostensibly reveals a complex distribution of the levels of religious diversity worldwide (fig. 1) but in very different political and cultural contexts.

And the ideological and praxeological horizon of diversity is obviously ... diverse! The French journal Courrier International has published another atlas (fig. 2) of the dynamics of religion: if diversity is distributed throughout the whole world, with a specific concentration in Europe, North America and Asia, but concomitantly and everywhere, especially in the South, the missionary pressure of monotheistic systems symbolizes the other face of religion in the contemporary world. Even so, the issue of mapping diversity is a complex one, since every geographic model is a reduction of reality, and since the different (and somewhat contradictory) logics of religious diversification cannot be all described together.

\section{Comparison and understanding}

What are we comparing when we talk about diversity in different contexts for different religious syscesses, the former referring to diversity at the scale of individuals, the latter pertaining to the dynamics of organizations or institutions. It is, furthermore, a truism to recall that the issue of diversity is everywhere encapsulated in a political context, the grounds on which public policies aim at the restriction or the promotion of religious diversity. But religious diversity also reflects, on a small scale, the dynamics of cultures and society that are happening on the global scene, and diversity can be a means of differentiating the forms of the sacred (identity-oriented, discriminant), or on the other hand, to accumulate sacred (mixing and adding, with mosaic effects). Can we conclusively typologize religious diversity, and to what extent are these models reliable and relevant? If we take into

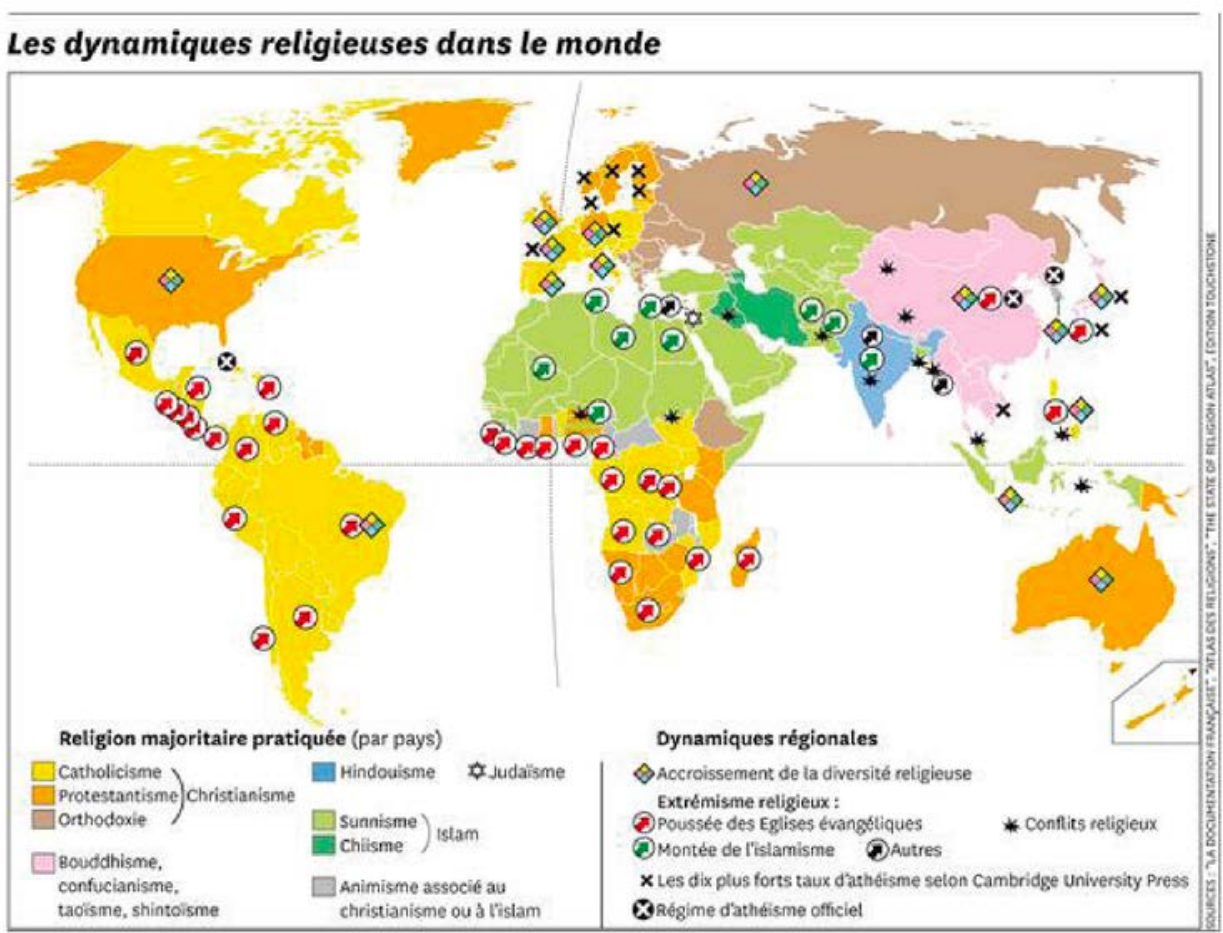

Fig. 2. Religious dynamics in the world. Courrier International 2013. 
tems? Do we compare situations, forms, ideas relating to diversity or diversities, that is to say, empiricallybased but theorized models of the variety of ways to act, believe and symbolize the sacred? Indeed, and considering the ideological background of the term, diversities are torn between two realms of reality: they can be embedded in social models, or on the reverse be theoretical models. Issues of terminology may also be of primary importance: diversity is empirical-ideological, pluralism is social, and multiculturalism is political in aims and forms. Faithful to its perspective and method, an anthropological study of diversity attempts to compare (scientific) models of realities and realities themselves. These models are composed of theoretical relations between elements of realities (beliefs, practices, organizations). Besides, the goal is to unveil the levels and logics of diversity. Such a perspective is undoubtedly fecund: the analysis is also embedded in moral geographies and imagination of the Other, especially the Western-style dichotomy of a unity here and now as opposed to a diversity there and before. In the moral geography of a self-styled 'secular-and-modern' West, Asian societies have been constructed as 'spiritual nations' (Van Der Veer 2009) and they figure out sites where one can frame genuine models, logics, shapes and dynamics of religious diversities.

It is also an epistemological commonplace to recall that, in the social sciences and humanities interested in religion, wide-scale theories (that are appealing to scholars and intellectuals for their ability to explain local realities in global terms) must always be addressed to down-to-earth and local realities. But if there is a clear peril of reductionism in overemphasizing the span of diversity as an 'essential' feature of Asian religions and societies, there is also a risk of confining the issue to a very local empirical reality, and therefore to restrict the issue to parochial views of the theoretical and political problem of religions coexisting and interacting in the same area. At the opposite pole stands the issue of the 'unity' of religions, and questions regarding the concept of a 'religious system. The use of the concept of a 'system' has remained unquestioned since Marcel Mauss set out to coin an 'operative' concept for an anthropological comparative study of religion (1908), and Roger Bastide's efforts to frame a distinctive series of criteria to specify the universal elements of religion from which the scholar would be able to conceive the diverse religious systems existing in human societies
(Bastide 1936). As such, a 'system' is far from being one of the concepts 'close to experience' (Geertz 1983): ordinary people (priests, devotees, laymen) are attached to traditions but not to systems. The existence of systemic (interactive and interdependent) relationships between religious beliefs, practices and organizations can be obvious and meaningful for some categories of people (elites), but not for others (masses). On that basis, what is an extension of the concept of a 'religious system'? It is a well-known fact that India, China or Japan epitomize models for a coexistence of traditions, with different schemes of integrations of traditions into a single system, but the terminology has long wavered between the singular (since 'the religion of the Chinese', Granet 1922) and the plural (with 'the religions of India', Weber 1958).

And finally, to what extent is the general character of Asiatic religiosity (in Weber's terms) (still) mixing traditions, while the religious history of the West, characterized by a political and cultural conquest of monotheism, has been oriented towards a 'polytheism of values'? A scholar like George Sioris (1988), though specializing in Tibet, seem to believe that syncretism (as a form) and tolerance (as an ideological background) are common, widespread, and even essential features of Buddhism in Asia as a whole. Diversity, nevertheless, demands to be questioned on the grounds of local investigations, detailed and informed case studies, capable of shedding light on different facets of diversity, and the shapes they assume, throughout Asia. This is why, although Asia remains a resource providing relevant models for theories of diversity, established on the comparison with diversification theories in the West, these models are far from being unified, either according to a single theory or a global and all-embracing conceptual framework. Issues in diversity are still addressed in different terminologies depending on the context: syncretism in Java (Geertz 1960), Nepal (Gellner 1997), hybridization in South-East Asia (Kitiarsa 2005), religious pluralism in India (Chatterjee 1994), or simply diversity in China (Weller 2014) epitomize only a few examples of the extended lexicon of the diverse expressions of religion in the Asian context.

This special issue is, in a certain way, an attempt to track notions of diversity, but also to prolong the debate and discuss the relevance of the issue.

Lionel Obadia, $\mathrm{PhD}$, is Professor in Anthropology at the University of Lyon 2, France, specializing in 


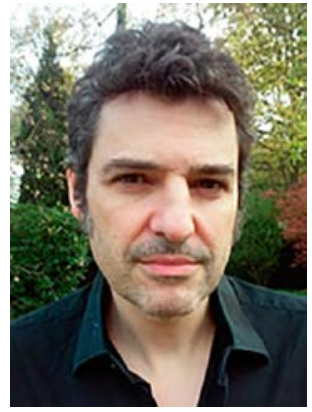

religious studies, anthropology and the sociology of religion. After gaining a $\mathrm{PhD}$ on Buddhism in France and in the West, he has studied Buddhism, shamanism and witchcraft in Asia, mainly Nepal. He has recently conducted research on Jewish Messianic movements in Europe, the US and Israel, and football (soccer) in a religious perspective in France. He is the author of ten books, among them Marchandisation de Dieu (2013), Anthropologie des religions (2007), Religion (2004), Sorcellerie (2004), Le bouddhisme en Occident (2007), and The Economics of Religion with Donald Wood (Emerald, 2011) and more than one hundred chapters and articles in French, English, Spanish, Chinese and German.

\section{Bibliography}

Appadurai, Arjun, 2001. 'Grassroots globalization and the research imagination' in Globalization, ed. Arjun Appadurai (Durham and London, Duke University Press), pp. 1-21

Baghramian, Maria, and Attracta Ingram (eds), 2000. Pluralism: The Philosophy and the Politics of Diversity (London and New York, Routledge)

Bastide, Roger, 1936. Eléments de sociologie religieuse (Paris, Armand Colin)

Beyer, Peter, 1994. Religion and Globalization (London, Sage)

-1998. 'The religious system of global society: a sociological look at contemporary religion and religions', Numen, 45, pp. 1-29

Bloom, Irene, J. Paul Martin, and Wayne L. Proudfoot (eds), 1996. Religious Diversity and Human Rights (New York, Columbian University Press)

Chatterjee, Margaret, 1994. 'Reflections on religious pluralism in the Indian context', Journal of HinduChristian Studies, 7, Article 5, pp. 2-12

Clémentin-Ojha, Catherine (ed.), 1997. Renouveaux Religieux en Asie (Paris, Ecole Française d'ExtrêmeOrient)

Courrier international 2013. 'En cartographie : les dynamiques religieuses de la planète, Courrier international, 27.3.2013, <http://www.courrierinternational.com/ article/2013/03/27/les-dieux-sont-de-retour $>$, (accessed 1.10.2015)

Csordas, Thomas (ed.), 2009. Transnational Transcendence: Essays on Religion and Globalization (Berkeley, University of California Press)

Foley, Edward (ed.), 2011. Religion, Diversity and Conflict (Berlin, Lit Verlag)

Friedman, Jonathan, 1994. Cultural Identity and Global Processes (London, Thousand Oaks; New Delhi, Sage)

García Canclini, Néstor, 1995. Hybrid Cultures: Strategies for Entering and Leaving Modernity (Minneapolis,
University of Minnesota Press)

Geertz, Clifford, 1960. The Religion of Java (New York, Free Press)

-1983. Local Knowledge: Further Essays in Interpretive Anthropology (New York, Basic Books)

-2000. 'The pinch of destiny: religion, experience, meaning, identity, power' in Clifford Geertz, Available Light: Anthropological Reflections on Philosophical Topics (Princeton University Press), pp. 167-86

Gellner, David, 1997. 'For syncretism: the position of Buddhism in Nepal and Japan compared', Social Anthropology, 5(3), pp. 277-91

Granet, Marcel, 1922. La religion des Chinois (Paris, Presses universitaires de France)

Habermas, Jürgen, 2006. 'Religion in the public sphere', European Journal of Philosophy, 14(1) April, pp. 1-25

Hannerz, Ulf, 1996. Transnational Connections: Culture, People, Places (London, Routledge)

Heelas Paul, and Linda Woodhead, 2005. The Spiritual Revolution: Why Religion is Giving Way to Spirituality (Oxford, Blackwell)

Hervieu-Léger, Danièle, 200o. Religion as a Chain of Memory (New Brunswick, NJ, Rutgers University Press)

Kitiarsa, Pattana, 2005. 'Beyond syncretism: hybridization of popular religion in contemporary Thailand', Journal of Southeast Asian Studies, 36(3) October, pp. 461-87

Küng, Hans, 1992. Judaism. Between Yesterday and Tomorrow (New York, Crossroad)

Luca, Nathalie, and Jean Burrell, 1999. 'Borrowings go round and round: transcending borders and religious flexibility', Diogenes, 47, pp. 3-10

Martino, Ernesto, de, 1948. Il mondo magico. Prolegomeni a una storia del magismo (Turín, Einaudi)

Mathews, Gordon, 2000. Global Culture/Individual Identity: Searching for Home in the Cultural Supermarket (London, Routledge)

Mauss, Marcel, (1908) 1968. Euvres, T. 1. Les fonctions sociales du sacré (Paris, Editions de Minuit)

Meintel, Deirde, and Marie-Nathalie Leblanc, 2003. 'La mobilité du religieux à l'ère de la globalisation', Anthropologie et sociétés, 27(1), pp. 5-11

Michelet, Jules, (1862) 1898. La sorcière (Paris, E. Flammarion)

Obadia, Lionel, 2010. 'Globalization and the sociology of religion' in The New Companion for the Sociology of Religion, ed. Bryan Turner (Oxford, Blackwell), pp. 477-97

-2011. 'Is Buddhism like a hamburger? Buddhism and the market economy in a globalized world, Research in Economic Anthropology, 31, pp. 99-121

-2013. Shalom Bouddha! Bouddhisme et judaïsme, l'improbable rencontre (Paris, Berg International)

-2014. 'Paradoxes, utopies et cécités du modernisme en religion : le cas du bouddhisme en France', Archives de Sciences Sociales des Religions, 167, juillet-septembre, pp. 295-316

-2015. 'Social and spatial visibility of religion in question: the case of pluricultural and multiconfes- 
sional France' in The Changing World Religion Map: Sacred Places, Identities, Practices and Politics, ed. Stanley D. Brunn (Dordrecht, Springer) pp. 1599-1614

PewResearchCenter, 2014. 'Global religious diversity: half of the most religiously diverse countries are in Asia-Pacific region, PewResearch Center, 4.4.2014, $<$ http://www.pewforum.org/2014/04/04/global-religious-diversity/> (accessed 2.8.2015)

Quinn, Philip L., and Kevin Meeker (eds), 200o. The Philosophical Challenge of Religious Diversity (New York, Oxford University Press)

Robertson, Roland, 1992. Social Theory and Global Culture (London, Thousand Oaks and New Delhi, Sage)

Sioris, George A. 1988, 'Buddhism in Asia: tolerance and syncretism', The Tibet Journal, 13(1), pp. 20-9

Tomlinson, John, 1999. Globalization and Culture (The University of Chicago Press)

Van der Veer, Peter, 2009, 'The comparative sociology of India and China', Social Anthropology, Special issue: 'Anthropology of Contemporary China', 17(1), pp. $90-100$

Vertovec, Steven, 2010. 'Towards post-multiculturalism? Changing communities, conditions and contexts of diversity', International Social Science Journal, 61(199), pp. 83-95

Voas, David, et al. 2002. 'Religious pluralism and participation: why previous research is wrong', American Sociological Review, 67(2), pp. 212-30

Waters, Malcolm, 2001. Globalization, 2nd edn (London, Routledge)

Weber, Max, (1916) 1958. The Religion of India: The Sociology of Hinduism and Buddhism (Glencoe, Free Press)

Weller, Robert P., 2014. 'The politics of increasing religious diversity in China, Daedalus, 143(2), pp. 135-44 Wieviorka, Michel, 2008. La diversité (Paris, Robert Laffont) 